\title{
Determinants of Board Contribution to Internal Controls and Good Governance: Evidence of Rural Banks in Ghana
}

\author{
Rauf Ibrahim (Corresponding author) \\ Jiangsu University, School of Management, P.R China \\ E-mail: rauljovial@yahoo.com \\ Du Jianguo (Professor) \\ Jiangsu University, School of Management, P.R China \\ E-mail: jgdu2005@163.com
}

\begin{abstract}
Santosh Rupa Jaladi (Professor)
Welingkar Institute of Management Development \& Research, India

E-mail: rupa.jaladi@gmail.com
\end{abstract}

\author{
Peter Lartey Yao \\ School of Finance and Economics, Jiangsu University \\ E-mail: efopeter@yahoo.com \\ Amponsah Clinton Kwabena \\ Jiangsu University \\ E-mail: klintoamponsah@gmil.com
}

Received: May 20, 2019 Accepted: July 8, 2019 Online published: November 8, 2019 doi:10.5296/jpag.v9i4.15766ＵRL: https://doi.org/10.5296/jpag.v9i4.15766 


\section{Abstract}

This article attempts to explain the factors that affect the board's behavior when it comes to enhancing internal controls in financial institutions, particularly rural banks. The variables examined in this study are not different from the traditional determinants of board effectiveness or internal controls, but except that between all the five variables measured four are technically board characteristics while one relates directly to internal controls. A total of 459 valid structured questionnaire were analyzed based on the feedback gathered from various banks where employees, management and board members shared their views on the factors that would influence the board's posture to enhance good governance and internal controls. The outcome of the study provided a convincing evidence that, internal audit, external consultancy and the audit committee are dominant determinants of internal control and good governance. Subsequent, examinations using the R square also confirms accuracy of predictions recorded in the principal component analysis. Further studies may analysis the size of the board relative to the increasing functions of ensuring compliance, independence and strategic decisions. This analysis is based on an African institutional context, but could be a universal tool.

Keywords: policy implementation, village fund, village independence

\section{Introduction}

Corporate governance is a well discussed concept in corporate business and still evolving in academia (Amore \& Bennedsen, 2016; Ararat, Black, \& Yurtoglu, 2017; Bahrawe, Haron, \& Hasan, 2016; Chen, Chen, Li, \& Ni, 2018). Governance has been in the centre of many discussions in literature as a result of increasing corporate scandals and many financial irregularities associated with businesses. There are positives and negative impacts of corporate governance, however, there increasing instances of the negative or the result of weak corporate governance contributed to the collapse and bankruptcy of many huge corporations in the early 1980's in the US, leading to the coming into existing of many regulations such as the Sarbanes-Oxley Act of 2002 and many laws. More especially, the collapse of Enron in early 1981 led to major reforms in corporate governance, which up to date (Altamuro \& Beatty, 2010). The regulations are simply set out to protect the interest of the larger stakeholders including investors, employees, shareholders, creditors, suppliers, governments, taxpayers and the general community who directly or indirectly have a vested interest in the operations of the corporation. But most importantly, investors, business partners were the most affected, therefore corporate governance came into existence to address all manner of inequalities associated with running an organisation on behalf of the owners and those who have a stake in those businesses (Barra, 2010). For example the Sarbanes - Oxley Act 2002, mandates companies to make their financial statement public, after it have been verified and properly audited by independent qualified persons. The opinions of the independent third party on the reliability of the accounts is what must be published (Caratas \& Spatariu, 2014). That fulfils the one aspect of the SOX regulations found in section 132. Additionally, the law directs corporations to have in place an internal control system to check their alignment with all applicable laws and constantly maintain 
compliance to those laws. In section 114, the firm is mandated to constitute a board that will oversee to the strategic plan, objective, draw risk management programmes and supervise over management in an independent fashion (Babatunde \& Dandago, 2014). There laws and regulations came into forces, however, it has not successfully achieved and a total accomplishment due to fraud, managerial greed and noncompliance issues. Though the laws have been applied strictly I certain countries and jurisdictions it advancement varies greatly among developing countries and some first world countries (Ge, Koester, \& McVay, 2017). By implication, it call for more empirical and theoretical investigations to examine which elements are working and which principles are not been applied and weak. This study aims at examining the contribution of the board to internal controls on the performance of selected rural banks in Ghana.

\section{Corporate Governance and Internal Control Systems}

Corporate governance is defined as the manner corporations, people and organisations are controlled. It often referred to as the basis of accountability, independence, decision making, collective thinking and consideration of the interest of group or the collective stakeholders (Afiah \& Azwari, 2015). The objectives and relevance of governance enforces ethical business practices, compliance with regulations and laws, efficient management of resources and judicious use and management of resources (Amore \& Bennedsen, 2016). The board have or is expected to hold certain critical characteristics that will make it relevant enough to influence growth, performance and achieving the strategic objectives of an enterprise. Historically, some characteristics have been tested by researchers in many jurisdictions, industries, companies and different sectors. Majority of these board characteristics have been very significant in determining the success of an organisation while others show no sign of statistical significance. Quiet recently Appiah, Asamoah, and Osei (2016), observed that among the determinants of board effectiveness and good governance, the size or composition of the boards is insignificant or it does not influence the effectiveness nor the performance of the organisation whether it's too small or too large. Ararat et al. (2017), concluded that independence of the board members is the most important factor that determines the board impact on the whole organisation. Baumgartner and Rauter (2017), also used leadership ability as a measure of the board effectiveness to impact positively on the performance of the organisation and found a strong relationship. Meanwhile Corkery and Taylor (2012), emphasized on education and qualification of members as the main measure of effectiveness and these was the subject they used to assess over 200 listed companies in Italy, and found a highly significance relationship. Among various banks, Dong, Girardone, and Kuo (2017), observed four characteristics that could improve the boards oversight responsibility to ensure performance and that included board accountability to stakeholders, their level of independence of management, the roles of the audit committee, the presence of a robust internal and well as the general commitment towards a strong internal control. All these terms and concepts add up to define corporate governance and the role of the board and how it influences the entire organisation. Singh and Vinnicombe (2004), the board can only be qualified to do its work perfectly only if the qualities and features that make it complete are present and enforced. 


\section{Key Determinants of Effectiveness of Internal Controls of Rural Banks.}

\subsubsection{Independent External Consultancy}

From stakeholder's perspective, a board that is committed to good governance in many occasions should possess the authority to seek for the services of independent external evaluators to conduct assessment on the organisation's operations without having to seek approval from management (Jiménez-Angueira and Carlos E. 2018). The board's authority to contract external evaluators to examine the affairs of the organisation should be supported with an independent financial budget controlled by the non-executive directors and not management (Schoon.M and Cox M. 2018). In cases where management had to negotiate and finance consultancy services such as external auditors fees, may compromise the board and may lead to undue influence, such as accept an outcome of audit and overlook possible wrongdoings (Chauhan, et al. 2016 ). In situations where management determines the remuneration, allowances and other financial benefits for the board and external evaluators, it could raise doubts on the quality and objectivity from stakeholder's perspective (Charest, Bouffard, \& Zajmovic, 2016; Liang, Chen, \& Chen, 2016). If the board is not autonomous in inviting a third party to evaluate the performance from an objective point of view at its own discretion and time, it certainly raises questions regarding transparency (Baumgartner, 2017). This also goes a long way indicate the influence management has over the board's decision on matters relating to the reputation and disclosure of relevant material information meant for the investor community and stakeholders (Bawole, 2016 ). This seem to suggest that, management can turn down the request by the board to hire external evaluators and it means that if management is not doing a good job, at a particular time it will definitely find reasons to postpone or raise objections against the request, then get a cover up (Bahrawe, 2016). It is therefore important to assess good governance from the independence of the board who represent the interest of stakeholder community (Chauhan, et al. 2016).

\subsubsection{Robust Internal Audit}

Since the owners of the company are not directly involve and in contact with the day-to day activities, they would definitely demand assurance from the director or their agents by way of representing their interest when taking decisions concerning the organisation (Shamim, Cang, $\& \mathrm{Yu}, 2017)$. This is where the relevance of the internal auditor comes to play, more especially where their work ensures compliance and addresses transparency issues.

Internal auditors ensure that the activities and operations of the organisation whether finance or non-financial in nature must apply certain acceptable principles that will demonstrate the existence of corporate governance that satisfies or are in line with the strategic objectives (Shrives \& Brennan, 2017). Internal auditors are often regarded as the custodians of internal controls and is often argued that, there is a bit of complexity when it comes to differentiating the roles of the internal auditors and the external auditors in relation who actually feeds the board of directors, and the audit committee and the chief executives of various governance and transparency issues (Neifar \& Jarboui, 2017). According to Gaitán, Herrera-Echeverri, and Pablo (2018), an organisation is just there to provide certain essential services at very reasonable cost, which means its profits are determined by the market forces, at the same 
time management is charged to deliver value to shareholders which also refers to dividends, but in doing so it must apply all necessary ethical standards to arrive at it short and long term objectives (Gupta, Krishnamurti, \& Tourani-Rad, 2018). Meanwhile Nazir and Afza (2018), believes that for the sake of simplicity, enterprise governance should be viewed as a universal concepts that seek to bring value based on efficiency and accountability rather than trying to compare whether the concept is suitable for corporate business (Seguí-Mas, 2018).

\subsubsection{Independence of Board of Directors}

There are several factors the goes in to determine the quality of the board of directors in line with ensuring effective and efficient governance which also influences the effectiveness of internal controls. The independence of directors of the organisation, company or entity is defined by their relationship with other parties that are associated with the affairs of the company (Chang, Yen, Chang, \& Jan, 2014). Here we refer to their relationship with management whom they are to supervise and check in accordance with specific standards to enhance transparency, accountability and ethical corporate behaviour. The challenges related to the relationship between board of directors and the board is often about transparency in accounting and financial reporting. Dowdell, Kim, Klamm, and Watson (2013), the board is a representative of the owners therefore they are expected to act interest of the owners in matters of accountability, reliability of finance and accounting information and governance issues which bothers on equal treatment when it comes to the interest of the broad stakeholders. However, in most cases the board is often caught exhibiting unethical relationships with management which goes a long way to tannish their reputation and often result in financial scandals (Jiang, Rupley, \& Wu, 2010). There are several regulations in recent time that guides the behaviour and conducts of the board such as maintaining high level of professionalism in discharging it duties by ensuring that their authority is not compromised. In many ways such policy include limiting the number of executive directors or maintaining a higher ratio of non-executive directors in order to ensure proper balance of power (Wilford, 2016). On the other hand, the role of the CEO and the board chairman must be clearly separated, but in case where the CEO acts as the board chairman, clear distinctions must be stated and powers limited to both duties and be strictly supervised by the board members as well as the non-executive directors (Liu, Lin, \& Shu, 2017). Additionally, diversity is an emerging issue that is meant to address board independence. It relates to the inclusion of female directors or maximum number of directors who against their male counterparts. In some advance countries this policy is getting significance results while it's still evolving among other jurisdictions.

\subsubsection{Educational Level of Board of Directors}

The quality of the boards and their contribution to the affairs of an organisation is dependent on several issues ( $\mathrm{Li}, \mathrm{Lim}, \&$ Wang, 2007). One of such issues or characteristics is the quality of educations or level of education of members. Many studies have argued that, the educational qualifications defines the quality of inputs made to the strategic objectives, while others maintain that education may not matter if the experience is there (Hotchkiss, 2016). Most often scholars, try to differentiate between successful organisations with members 
having less education but appointed based on experience and those that are simply selected based on the qualification they hold. McCarthy, Puffer, and Shekshnia (2004), argued that the level of educations or qualification simply defines the competence, technical knowledge of the directors, since their job is much more complicated and require category of people with high expertise in diverse backgrounds. Robbins and Meyer (2016), supported the argument saying that the only way the board can stay relevant and be efficient enough to draw the strategic roadmap for the organisation is to be composed of a group of intellectuals and persons with vast knowledge in what they have been tasked to do as leaders of an organisation, however, anything short of this will lead to bankruptcy and inefficiencies

\subsubsection{The Role of the Audit Committee}

The audit committee forms part of the board and it job is related to ensuring transparency, compliance and ethical financial practices (Matei \& Drumasu, 2015). Part of their job includes promoting a high level reliability of financial reporting to stakeholders and shareholders. The audit committee is an integral part of the board consisting of only nonexecutive members whose duty spans through the whole organisation (Johanson, 2019). They ensure effectiveness of internal controls through monitoring and liaising with external auditors to focus attention on areas of risk and financial irregularities (Bhaskar, Schroeder, \& Shepardson, 2018). With regards to appointment, fixing remunerations of the board members and determining salaries packages of management and the most reward packages, the audit committee has to be vested in such issues. Audit committees enhances internal controls through several frameworks, such as the use of computerized accounting systems to monitor the accuracy of recording financial transactions to presenting reliable information to stakeholders (Black, De Carvalho, Khanna, Kim, \& Yurtoglu, 2018). Their supervisory role help reduce, errors, identify fraud and malpractices, but this is only possible if members are vested in accounting and finance, to enable them to read and understand the information management has put before them, and if it require recommendation, criticisms and correction, they can do so and ensure that the interest of owners is always protected.

\section{Methodology and Research Design}

Due to lack of relevant sufficient empirical studies on this subject, particularly the contribution of the board to the effectiveness of internal controls, this study focuses exploring the research agenda using quantitative and qualitative approach. The study relates to previous studies in other countries and jurisdictions and attempt to draw lessons from various existing examples and compare to this findings and then contribute to the research agenda and add to the discussion on good governance and its relationship with internal controls, financial and accounting management. According to (Sullivan, 2012), a case study method is the ideal research method for performing an exploratory study, mostly if the study is meant to offer a comprehensive explanation to some existing problems that have not previously been examined thoroughly. The study, employed various statistical techniques in addition to content analysis. In views of Wang, Xie, and Zhu (2015), case study method is extensively applied and it is tested in business and suitable for performing content analysis in a more rigorous fashion, with the purposes of analyzing a business strategy. Additionally Rupp 
(1994), case is arguably the best approach to analyze and examine contemporary corporate issues confronting business operations, in a real life context Sarens, De Beelde, and Everaert (2009). Going by this, the quantitate analysis will be done using the feedback from questionnaires while qualitative analysis will make use of disclosures in the annual reports and documented governance and internal control principles guiding operations of the banks. The reliability of this approach is found in Geisser (1974).

\subsubsection{Research Approach}

The study adopted a cross sectional dimension and technically a mix of explanatory and quantitative in nature (Block, Miller, \& Wagner, 2014). Primary data is gathered using structured questionnaires administered to staff and management of 15 rural banks, including board members, within the northern region of Ghana. Preliminary data shows that the respondents fall within the ages of $25-59$ years on average.

\subsubsection{The Sample Size}

The population forming the target respondents for this study include, employees in the banking sector, board members and management staff (Bolland, Gamble, Avenell, \& Grey, 2019). The respondents were conveniently samples from different departments such as, finance, internal audit, administration, transport, bank corporate affairs which is the board and the lower ranks (Hannigan \& Lynch, 2013). Although other departments like marketing, promotion and advertising departments are not actively participating in the study, the generalization of the outcome would reflect the entire banking industry and the inform the judgment of the researchers about the contribution of governance to internal controls rural banks in Ghana. A total of 459 participant's respondent with their feedback and this return rate is considered suitable enough to perform an inferential judgment on the general population. Majority of about $70 \%$ of the respondents also fall within the educational category of undergraduate and postgraduate, while $10 \%$ are $\mathrm{PhD}$ holders.

\subsubsection{The Structure of the Questionnaires}

The questionnaire was drafted in English since that is the official language spoken in Ghana and it's the working language in all banks in Ghana including the foreign banks. Additionally, the questionnaires administration was carried out by the customer service and front desk employees who ensured that each employee of the bank gaining entry of the banks is issued a copy and returned within 5 working days. It was measured on 5 point Likert, with each constructed measured based on 4 items. This measures the relationship between determinants on board contribution to controls and effectiveness of controls which we adopted from (Nazari, 2010). The reliability of the data set and constructs is measured using Crombach's alpha test of internal consistency. 
Table 1. Reliability test

\begin{tabular}{l|l|l}
\hline Variables & $\begin{array}{l}\text { Coefficient } \\
\text { values }\end{array}$ & Difference \\
\hline Good Governance & 0.078 & Variables meets criteria \\
\hline Independent External Consultancy & 0.701 & Variables meets criteria \\
\hline Robust Internal Control & 0.824 & Variables meets criteria \\
\hline Independent Board & 0.792 & Variables meets criteria \\
\hline Audit Committee & 0.834 & Variables meets criteria \\
\hline Board Member Education & 0.702 & Variables meets criteria \\
\hline
\end{tabular}

Table 1, illustrates the variable reliability test based on Cronbach's internal consistency criteria. The constructs consist of six items measuring both the dependent (Good governance) and 5 independent variables. The variables from a technical view point meet the criteria of the internal consistency of $0.7 \%$ threshold. This implies that, the data is fit for subsequent analysis based on the positive coefficient values. This criteria is extensively applied in social science research due to its accuracy and reliability, major evidence can be found in (Block et al., 2014)

\subsubsection{Empirical Results and Analysis}

This research examines the contribution of the board to internal control effectiveness and the factors that influences the board to act in this manner. Various instances of financial scandals have point to the fact that management is most often the victim, however less is attributed to the board. The study is one the few research works, that is attempting to relate the effectiveness of internal control to the board and the overall corporate governance structure and its determinants. Additionally, the study then explores the relationship between the five independent variables and one dependent variable.

Table 2. Hypothesis testing

\begin{tabular}{|c|c|c|c|c|}
\hline Hypothesis & Std Dev. & t-value & P-value & Decisions \\
\hline $\begin{array}{l}\text { (H1) Management demonstrate commitment to good } \\
\text { governance principles }\end{array}$ & 0.682 & 2.461 & 0.001 & supports \\
\hline (H2) Independent board will influence control & 0.522 & 1.306 & 0.022 & supports \\
\hline $\begin{array}{l}\text { (H3) Robust internal audit impacts significantly supports } \\
\text { good governance and controls }\end{array}$ & 0.205 & 3.772 & 0.000 & supports \\
\hline $\begin{array}{l}\text { (H4) Requisite educational qualification determines board } \\
\text { performance and governance }\end{array}$ & 0.194 & 4.221 & 0.000 & supports \\
\hline $\begin{array}{l}\text { (H5)Effective Audit committee id key to good governance } \\
\text { and internal controls }\end{array}$ & 0.324 & 2.603 & 0.003 & supports \\
\hline
\end{tabular}

From table 2 above, each independent variable tested produced a positive $\mathrm{p}$ value, which directly implies that, the variables measured are good determinants of good governance which also by implication influences internal control effectiveness. Technically, the audit committee, internal audit and external consultancy which is mostly made up of external 
auditors, traditionally influences internal controls compliance. However, the relationship between the board and their commitment to internal control has not been extensively studied, and if at all there has not been any decisive as to what exactly influences the board to protect the integrity of internal control structures in an organization (Collier, 2009). The significance level of each construct is an indication that, the null hypothesis may be rejected and sustain the alternate hypothesis and maintain that, the independent variables measured in this study significantly impact governance and internal controls effectiveness, hence the decision to support the alternate hypothesis at each p-value less than 0.05 . The respective variance mean that each independent variables will cause a great impact and each unit of that will increase internal control and good governance per the t-values and the standard deviation. But the t-values also imply that there difference between al the constructs.

$$
\mathrm{Y}_{\mathrm{i}}=\beta_{0}+\beta_{1} \mathrm{X}_{\mathrm{i}}+\varepsilon_{\mathrm{i}}
$$

In table 3, is a Principal Component Analysis, showing the \% variance caused on the dependent variable and clearly illustrated by the model. Aside the total variance which is the cumulative $\%$ variance, the model also states how the individual variables caused a change in the dependent variable. This variations confirms the estimated effect of the explanatory variables if the determinants of governance are put in place by management of the banks.

The result is a significant implication to exiting literature and theory relating to the relationship between corporate governance and internal controls according to Ayuso and Argandoña (2009), it was previously stated that internal audit have a negative impact on corporate governance because they are appointed and managed by management and they form part of the organization therefore can never be independent enough influence good governance. This theory has just been disproved by the outcome of this study. The result suggest that the audit committee is a good determinant of board contribution to internal control. In other studiesHagigi and Sivakumar (2009), this component measured significant because the audit committee along with the external auditor who are referee to here as the external consultancy, is also a good determinant of compliance. The model present a total variance of $82.682 \%$ by three dominant factors. The dominant variables include the Audit committee, internal audit and external consultancy who constitute the services of external auditors. Similar findings, have shown that these factors are good determinants, meanwhile the other two factors made up of board member educational level and independent board members did not cause significant variance but in a way have moderate impact and therefore could form part of major management decisions (Huang, Yen, Hung, Zhou, \& Hua, 2009). The principal Component Analysis, has caused a reduction in the dimension of the data set resulting in the reporting of the three most dominant variables with their respective positive coefficients. This outcome suggest that, management decision on internal control can now include the board actively for a positive contribution provided the five variables are effectively implemented. 29.291\% variance will occur if audit committee is improved and becomes independent (Kim \& Mauborgne, 2009). $34.032 \%$ variance or improvement will be added internal audit is enhanced and maintain its independence of management and continues to be the custodian of internal control systems. $19.3559 \%$ is what external auditor will 
contribute to the quality of internal control and governance if all things being equal, and that will lead to them discovering more evidence of fraudulent activities and correcting deviations from internal control standards.

Table 3. Principal Component Analysis

\begin{tabular}{ccccccc}
\hline \multirow{2}{*}{ Components } & \multicolumn{3}{c}{ Eigenvalue } & \multicolumn{2}{c}{ Extracted } & \multicolumn{2}{c}{ Sum of Square Loading } \\
\cline { 2 - 7 } & \multirow{2}{*}{ total } & Variance \% & cumulative \% & total & \multirow{2}{*}{ Variance \% } & \multirow{2}{*}{ cumulative } \\
\hline 1 & 0.602 & 29.291 & 29.291 & 0.602 & 29.291 & 29.291 \\
2 & 2.201 & 34.032 & 63.323 & 2.201 & 34.032 & 63.323 \\
3 & 0.272 & 19.359 & 82.682 & 0.272 & 19.359 & 82.682 \\
4 & 1.740 & 16.292 & 98.974 & & & \\
5 & 1.461 & 1.026 & 100.000 & & & \\
\hline
\end{tabular}

In table 4 below, we went further to measure the absolute predictive power of the model by applying a discriminant analysis to find out the exact size of effect or the degree of variability. It could observed from table, 4, that using the Nagelkerke's criterion, the model predicted $72.90 \%$ variance which is also referred to as the R-squares. By implication it could be conclude that, the model satisfactorily explains internal controls from the perspective of governance.

Table 4. Discriminant Analysis R-Square

\begin{tabular}{cc}
\hline Cox and snell Criterion & $83.3 \%$ \\
\hline Nagelkerke's Criterion & $72.9 \%$ \\
\hline McFadden's Criterion & $84.0 \%$ \\
\hline
\end{tabular}

Nagelkerke's criterion is considered as the actual estimated or proportion the variation caused on the dependent variables, and it great enough to enhance management decision to improve internal controls, in the sense that, the remaining $27.9 \%$ could be attributed to the other factors that may affect internal control and the board but were excluded or falls outside the scope of this study.

The $\mathrm{R}^{2}$ form the basis for management decisions in order to achieve the operational objective, strategic, compliance and financial reporting objectives. The model pose a good characteristic that will inform a better approach to the board's involvement in enhancing internal controls. Overall the $\mathrm{R}^{2}$ also infers that the null hypothesis be rejected and by implication conclude that the independent variables are good determinants of internal control at significant $0.000 \mathrm{p}$ value, also implying a goodness of fit based the data reliability and the degree of association between the constructs.

\section{Conclusion and Discussion and Theoretical Relevance}

The role of the board is relevant ad cannot be over emphasized, especially when it concerns banking institutions. Many studies have assessed the board using the most traditional factors that determines the effectiveness of the board such as ; the independence of members, diversity and ratio of female directors, board member qualification, accountability and the role of the audit committee (Brammer, Millington, \& Pavelin, 2007). In most of these case, the studies relates to and limited to the effectiveness the board and not necessarily looking at 
the boards contribution to internal controls (Doyle, Ge, \& McVay, 2007). This is because, technically the board's role is different from that of management and the authority is clearly defined. For example whereas management is focusing on internal control systems, the board with its sub-committees such as the audit committee may be engaged in analyzing risk, and governance and strategic issues (Kong, Lartey, Bah, \& Biswas, 2018). This is where this current research attempts to bridge the gap between the board and effectiveness of internal control by looking at those tools and institutional variables that the board can rely on to examine and influence and improve internal control without necessarily interfering with management role. According to the findings, the board can influence internal control by ensuring that internal audit is robust and that it is independent of management. Independent enough to ensure compliance and check irregularities. At the same time the board can determine the effectiveness of control by ensuring the audit committee is very functional and well constituted. This way Gursoy and Swanger (2007), the audit committee of the board must be constituted a maximum non-executive members, for the purposes of independence and ethical practices. We are not surprised that, board member qualification did not cause a significant impact on the board. It means that among the banks, the performance of the board does not necessarily have to with the educational level of members. Over all the statistical tools provided a significant evidence to support the idea that, the boards role should not be limited to just policies, it have to ensure other key aspects of the organization that will encourage the achievement of the strategic objective are given the necessary consideration. On the issue of duality and independence of the CEO in acting in an independent fashion, especially in cases where the CEO hold acts the board chairperson, clear guidelines must be provided by the board to limit the power and authority of the CEO, most especially when it comes to granting approvals to payments. For empirical studies, the size of the board can be examined to determine whether a larger board could mean that the board will be well resourced enough to handle all aspects of controls from operations, compliance, independence, risk management and financial reporting issues.

\section{References}

Afiah, N. N., \& Azwari, P. C. (2015). The Effect of the Implementation of Government Internal Control System (GICS) on the Quality of Financial Reporting of the Local Government and its Impact on the Principles of Good Governance: A Research in District, City, and Provincial Government in South Sumatera. Procedia - Social and Behavioral Sciences, 211, 811-818. https://doi.org/10.1016/j.sbspro.2015.11.172

Altamuro, J., \& Beatty, A. (2010). How does internal control regulation affect financial reporting? Journal of Accounting and Economics, 49(1), 58-74. https://doi.org/10.1016/j.jacceco.2009.07.002

Amore, M. D., \& Bennedsen, M. (2016). Corporate governance and green innovation. Journal of Environmental Economics and Management, 75, 54-72. https://doi.org/10.1016/j.jeem.2015.11.003

Appiah, K. O., Asamoah, L. A., \& Osei, B. (2016). Nomination committee-board gender diversity nexus in Ghana. International Journal of Business Governance and Ethics, 11(2), 
135-158. https://doi.org/10.1504/IJBGE.2016.078217

Ararat, M., Black, B. S., \& Yurtoglu, B. B. (2017). The effect of corporate governance on firm value and profitability: Time-series evidence from Turkey. Emerging Markets Review, 30, 113-132. https://doi.org/10.1016/j.ememar.2016.10.001

Ayuso, S., \& Argandoña, A. (2009). Responsible corporate governance: towards a stakeholder board of directors? https://doi.org/10.2139/ssrn.1349090

Babatunde, S. A., \& Dandago, K. I. (2014). Internal Control System Deficiency and Capital Project Mis-management in the Nigerian Public Sector. Procedia - Social and Behavioral Sciences, 164, 208-221. https://doi.org/10.1016/j.sbspro.2014.11.069

Bahrawe, S. H., Haron, H., \& Hasan, A. N. B. (2016). Corporate Governance and Auditor Independence in Saudi Arabia: Literature Review and Proposed Conceptual Framework. International Business Research, 9(11), 1. https://doi.org/10.5539/ibr.v9n11p1

Barra, R. A. (2010). The impact of internal controls and penalties on fraud. Journal of information systems, 24(1), 1-21. https://doi.org/10.2308/jis.2010.24.1.1

Baumgartner, R. J., \& Rauter, R. (2017). Strategic perspectives of corporate sustainability management to develop a sustainable organization. Journal of Cleaner Production, 140, Part 1, 81-92. https://doi.org/10.1016/j.jclepro.2016.04.146

Bhaskar, L. S., Schroeder, J. H., \& Shepardson, M. L. (2018). Integration of Internal Control and Financial Statement Audits: Are Two Audits Better than One? The Accounting Review. https://doi.org/10.2308/accr-52197

Black, B. S., De Carvalho, A. G., Khanna, V. S., Kim, W., \& Yurtoglu, B. B. (2018). Which Aspects of Corporate Governance Matter in Emerging Markets: Evidence from Brazil, India, Korea, and Turkey. Northwestern Law \& Econ Research Paper(14-22).

Block, J. H., Miller, D., \& Wagner, D. (2014). Bayesian methods in family business research. Journal of Family Business Strategy, 5(1), 97-104. https://doi.org/10.1016/j.jfbs.2013.12.003

Bolland, M. J., Gamble, G. D., Avenell, A., \& Grey, A. (2019). Rounding, but not randomization method, non-normality, or correlation, affected baseline P-value distributions in randomized trials. Journal of Clinical Epidemiology, 110, 50-62. https://doi.org/10.1016/j.jclinepi.2019.03.001

Brammer, S., Millington, A., \& Pavelin, S. (2007). Gender and ethnic diversity among UK corporate boards. Corporate Governance: An International Review, 15(2), 393-403. https://doi.org/10.1111/j.1467-8683.2007.00569.x

Caratas, M. A., \& Spatariu, E. C. (2014). Contemporary Approaches in Internal Audit. $\begin{array}{llll}\text { Procedia Economics } \quad \text { Finance, 530-537. } & \text { 15, }\end{array}$ https://doi.org/10.1016/S2212-5671(14)00503-6

Chang, S.-I., Yen, D. C., Chang, I. C., \& Jan, D. (2014). Internal control framework for a compliant ERP system. Information \& Management, 51(2), 187-205. 
https://doi.org/10.1016/j.im.2013.11.002

Charest, F., Bouffard, J., \& Zajmovic, E. (2016). Public relations and social media: Deliberate or creative strategic planning. Public Relations Review, 42(4), 530-538. https://doi.org/10.1016/j.pubrev.2016.03.008

Chen, D., Chen, Y., Li, O. Z., \& Ni, C. (2018). Foreign residency rights and corporate fraud. Journal of Corporate Finance, 51, 142-163. https://doi.org/10.1016/j.jcorpfin.2018.05.004

Collier, P. M. (2009). Chapter 23 - The Audit Committee, Enterprise Risk Management and Internal Control. In P. M. Collier (Ed.), Fundamentals of Risk Management for Accountants and Managers (pp. 245-259). Oxford: Butterworth-Heinemann. https://doi.org/10.1016/B978-0-7506-8650-1.00023-7

Corkery, J. F., \& Taylor, M. (2012). The gender gap: A quota for women on the board. Enterprise Governance eJournal, 1(1), 6924.

Dong, Y., Girardone, C., \& Kuo, J.-M. (2017). Governance, efficiency and risk taking in Chinese banking. The British Accounting Review, 49(2), 211-229. https://doi.org/10.1016/j.bar.2016.08.001

Dowdell, T. D., Kim, J.-C., Klamm, B. K., \& Watson, M. W. (2013). Internal control reporting and market liquidity. Research in Accounting Regulation, 25(1), 30-40. https://doi.org/10.1016/j.racreg.2012.11.009

Doyle, J., Ge, W., \& McVay, S. (2007). Determinants of weaknesses in internal control over financial reporting. Journal of Accounting and Economics, 44(1), 193-223. https://doi.org/10.1016/j.jacceco.2006.10.003

Gaitán, S., Herrera-Echeverri, H., \& Pablo, E. (2018). How corporate governance affects productivity in civil-law business environments: Evidence from Latin America. Global Finance Journal, 37, 173-185. https://doi.org/10.1016/j.gfj.2018.05.004

Ge, W., Koester, A., \& McVay, S. (2017). Benefits and costs of Sarbanes-Oxley Section 404 (b) exemption: Evidence from small firms' internal control disclosures. Journal of Accounting and Economics. https://doi.org/10.1016/j.jacceco.2017.01.001

Geisser, S. (1974). A predictive approach to the random effect model. Biometrika, 61.1(101-107.). https://doi.org/10.1093/biomet/61.1.101

Gupta, K., Krishnamurti, C., \& Tourani-Rad, A. (2018). Financial development, corporate governance and cost of equity capital. Journal of Contemporary Accounting \& Economics, 14(1), 65-82. https://doi.org/10.1016/j.jcae.2018.02.001

Gursoy, D., \& Swanger, N. (2007). Performance-enhancing internal strategic factors and competencies: Impacts on financial success. International Journal of Hospitality Management, 26(1), 213-227. https://doi.org/10.1016/j.ijhm.2006.01.004

Hagigi, M., \& Sivakumar, K. (2009). Managing diverse risks: An integrative framework. Journal of International Management, 15(3), 286-295. 
https://doi.org/10.1016/j.intman.2009.01.001

Hannigan, A., \& Lynch, C. D. (2013). Statistical methodology in oral and dental research: Pitfalls and recommendations. Journal of Dentistry, 41(5), 385-392. https://doi.org/10.1016/j.jdent.2013.02.013

Hotchkiss, D. (2016). Governance and ministry: Rethinking board leadership: Rowman \& Littlefield.

Huang, S.-M., Yen, D. C., Hung, Y.-C., Zhou, Y.-J., \& Hua, J.-S. (2009). A business process gap detecting mechanism between information system process flow and internal control flow. Decision Support Systems, 47(4), 436-454. https://doi.org/10.1016/j.dss.2009.04.011

Jiang, W., Rupley, K. H., \& Wu, J. (2010). Internal control deficiencies and the issuance of going concern opinions. Research in Accounting Regulation, 22(1), 40-46. https://doi.org/10.1016/j.racreg.2009.11.002

Johanson, J.-E. (2019). Internal Strategic Scanning Strategy Formation and Policy Making in Government (pp. 121-142): Springer. https://doi.org/10.1007/978-3-030-03439-9

Kim, W. C., \& Mauborgne, R. (2009). How strategy shapes structure. Harvard Business Review, 87(9), 72-80.

Kong, Y., Lartey, P., Bah, F., \& Biswas, N. (2018). The Value of Public Sector Risk Management: An Empirical Assessment of Ghana. Administrative Sciences, 8(3), 40. https://doi.org/10.3390/admsci8030040

Li, C., Lim, J.-H., \& Wang, Q. (2007). Internal and external influences on IT control governance. International Journal of Accounting Information Systems, 8(4), 225-239. https://doi.org/10.1016/j.accinf.2007.09.002

Liang, H.-Y., Chen, I. J., \& Chen, S.-S. (2016). Does corporate governance mitigate bank diversification discount? International Review of Economics \& Finance, 45, 129-143. https://doi.org/10.1016/j.iref.2016.05.008

Liu, C., Lin, B., \& Shu, W. (2017). Employee quality, monitoring environment and internal control. China Journal of Accounting Research, 10(1), 51-70. https://doi.org/10.1016/j.cjar.2016.12.002

Matei, A., \& Drumasu, C. (2015). Corporate Governance and Public Sector Entities. Procedia Economics and Finance, 26, 495-504. https://doi.org/10.1016/S2212-5671(15)00879-5

McCarthy, D. J., Puffer, S. M., \& Shekshnia, S. V. (2004). Corporate governance in Russia: Edward Elgar Publishing.

Nazari, M. (2010). Design and process of a contextual study of information literacy: An Eisenhardt approach. Library \& Information Science Research, 32(3), 179-191. https://doi.org/10.1016/j.lisr.2010.02.003

Nazir, M. S., \& Afza, T. (2018). Does managerial behavior of managing earnings mitigate the 
relationship between corporate governance and firm value? Evidence from an emerging market. Future Business Journal, 4(1), 139-156. https://doi.org/10.1016/j.fbj.2018.03.001

Neifar, S., \& Jarboui, A. (2017). Corporate governance and operational risk voluntary disclosure: Evidence from Islamic banks. Research in International Business and Finance. https://doi.org/10.1016/j.ribaf.2017.09.006

Robbins, M., \& Meyer, M. (2016). Auditing the National HR Standards: governance: HR standards. HR Future, 2(Feb 2016), 25-27.

Rupp, W. T. (1994). Qualitative Evaluation and Research Methods: Michael Quinn Patton, Sage Publications, Newbury Park, CA. 1990. Journal of Business Research, 30(2), 197-199. https://doi.org/10.1016/0148-2963(94)90038-8

Sarens, G., De Beelde, I., \& Everaert, P. (2009). Internal audit: A comfort provider to the audit committee. The British Accounting Review, 41(2), 90-106. https://doi.org/10.1016/j.bar.2009.02.002

Seguí-Mas, E. B.-A., Helena-María Polo-Garrido, Fernando. (2018). Assurance on Corporate Governance Reports in Spain: Towards an Enhanced Accountability or a New Form of Public Relations? Administrative Sciences, 8(3), 32. https://doi.org/10.3390/admsci8030032

Shamim, S., Cang, S., \& Yu, H. (2017). Supervisory orientation, employee goal orientation, and knowledge management among front line hotel employees. International Journal of Hospitality Management, 62, 21-32. https://doi.org/10.1016/j.ijhm.2016.11.013

Shrives, P. J., \& Brennan, N. M. (2017). Explanations for corporate governance non-compliance: A rhetorical analysis. Critical Perspectives on Accounting, 49, 31-56. https://doi.org/10.1016/j.cpa.2017.08.003

Singh, V., \& Vinnicombe, S. (2004). Why so few women directors in top UK boardrooms? Evidence and theoretical explanations. Corporate Governance: An International Review, 12(4), 479-488. https://doi.org/10.1111/j.1467-8683.2004.00388.x

Sullivan, G. M., and Richard Feinn. (2012). Using effect size —or why the P value is not enough. Journal of graduate medical education, 4.3, 279-282. https://doi.org/10.4300/JGME-D-12-00156.1

Wang, C., Xie, F., \& Zhu, M. (2015). Industry expertise of independent directors and board monitoring. Journal of Financial and Quantitative Analysis, 50(05), 929-962. https://doi.org/10.1017/S0022109015000459

Wilford, A. L. (2016). Internal control reporting and accounting standards: A cross-country comparison. Journal of Accounting and Public Policy, 35(3), 276-302. https://doi.org/10.1016/j.jaccpubpol.2015.12.006 


\section{Copyright Disclaimer}

Copyright for this article is retained by the author(s), with first publication rights granted to the journal.

This is an open-access article distributed under the terms and conditions of the Creative Commons Attribution license (http://creativecommons.org/licenses/by/4.0/). 